\title{
Early clinical experience with 'splenic switch-off' in adenosine stress CMR
}

\author{
Jennifer Bryant", Ausami Abbas, Stephen Harden, Steve George, James Shambrook, Charles Peebles \\ From 18th Annual SCMR Scientific Sessions \\ Nice, France. 4-7 February 2015
}

\section{Background}

MRI Adenosine stress perfusion is a well-established method of evaluating myocardial ischaemia but we know from a number of studies that false negatives are a potential weakness of this modality. Assessment of splenic perfusion at stress and rest (splenic switch-off) has recently been suggested as a means of identifying true pharmacological stress response to adenosine [1]. This is a promising technique but can only be assessed after the stress procedure. The aim of this study was to compare symptomatic and haemodynamic response with visual assessment of splenic perfusion during stress and rest perfusion imaging to see if we could accurately predict those who would have absent splenic switch-off.

\section{Methods}

We retrospectively reviewed all patients who completed a standard adenosine perfusion CMR over 2 months at a single centre. Adenosine was administered at a standard dose of $140 \mu \mathrm{g} / \mathrm{kg} / \mathrm{min}$ for at least 3 minutes prior to perfusion imaging. Adequate haemodynamic response was considered as a heartrate increase $\geq 10 \mathrm{bpm}$ and/or $\mathrm{SBP}$ decrease $\geq 10 \mathrm{mmHg}$. Appropriate symptomatic response included facial flushing, breathlessness and chest tightness. According to current clinical practice concurrent haemodynamic and symptomatic response was taken to indicate adequate physiological stress. Splenic switch-off was assessed by visual comparison between stress and rest images.

\section{Results}

145 patients attended for stress. All patients exhibited a response to adenosine. The spleen was not visible on the images of 4 patients $(2.8 \%)$. Patients were divided into two categories; those who had a single response haemodynamic or symptomatic; and those who had a dual response - both haemodynamic and symptomatic (Table 1).Splenic switch-off was visualized in one of 3 (33\%) who had a haemodynamic response only and in 16 of $26(62 \%)$ who had a symptomatic response only. Patients experiencing both a haemodynamic and symptomatic response were more likely to reflect adequate stress with splenic switch-off when compared with those experiencing a single response $(\mathrm{p}<0.001)$.

\section{Conclusions}

Using splenic switch-off as the gold standard assessment for adequate pharmacological response there was a good correlation with those who experienced both a haemodynamic and symptomatic response. We should consider increasing adenosine dose when patients show only a single haemodynamic or symptomatic response.

Table 1 Splenic switch-off related to adenosine response

\begin{tabular}{|c|c|c|c|c|c|}
\hline & \multicolumn{3}{|c|}{ Response to adenosine } & & \\
\hline & Single & Dual & Total & & \\
\hline \multirow[t]{2}{*}{ Splenic switch-off } & $\mathrm{NO}$ & Number (\%) & $12(41.4 \%)$ & 7 (6.3\%) & 19 (13.5\%) \\
\hline & YES & Number (\%) & 17 (58.6\%) & $105(93.8 \%)$ & $122(86.5 \%)$ \\
\hline Total & \multicolumn{2}{|c|}{ Number (\% of total) } & $29(20.6 \%)$ & $112(79.4 \%)$ & $141(100 \%)$ \\
\hline
\end{tabular}

University Hospital Southampton NHS Foundation Trust, Southampton, UK 


\section{Funding}

N/A.

Published: 3 February 2015

\section{Reference}

1. Manisty C, Ripley D, Captur G, Peebles C, Wong T, Schelbert E, Herrey A,

Greenwood J, Moon J: 'Splenic switch-off' to detect adenosine

understress; a novel method to improve test sensitivity. Journal of

Cardiovascular Magnetic

Resonance 2014, 16(Suppl 1):01.

doi:10.1186/1532-429X-17-S1-P91

Cite this article as: Bryant et al.: Early clinical experience with 'splenic switch-off' in adenosine stress CMR. Journal of Cardiovascular Magnetic Resonance 2015 17(Suppl 1):P91.

Submit your next manuscript to BioMed Central and take full advantage of:

- Convenient online submission

- Thorough peer review

- No space constraints or color figure charges

- Immediate publication on acceptance

- Inclusion in PubMed, CAS, Scopus and Google Scholar

- Research which is freely available for redistribution

Submit your manuscript at www.biomedcentral.com/submit
C Biomed Central 